\title{
TROPHIC GROUPS OF DEMERSAL FISH OF SANTOS BAY AND ADJACENT CONTINENTAL SHELF, SÃO PAULO STATE, BRAZIL: TEMPORAL AND SPATIAL COMPARISONS
}

\author{
Elizabeti Y. Muto ${ }^{l, *}$, Thaïs Navajas Corbisier ${ }^{1}$, Leandro Inoe Coelho ${ }^{1}$, Lidia Paes Leme Arantes ${ }^{l}$, \\ André Chalom ${ }^{2}$ and Lucy Satiko Hashimoto Soares ${ }^{l}$ \\ ${ }^{1}$ Instituto Oceanográfico da Universidade de São Paulo \\ (Praça do Oceanográfico, 191, 05508-120 São Paulo, SP, Brasil) \\ ${ }^{2}$ Instituto de Matemática e Estatística da Universidade de São Paulo \\ (Rua do Matão 1010, 05508-050 São Paulo, SP, Brasil) \\ *Corresponding author: mutokika@gmail.com
}

http://dx.doi.org/10.1590/S1679-87592014045906202

\begin{abstract}
A B S T R A C T
The temporal and spatial variations of feeding habits and trophic groups of demersal fish species of Santos Bay and the adjacent continental shelf were investigated. The samples were taken in September 2005 and March 2006 by bottom otter trawling. The stomach content analysis of 2,328 specimens of 49 species showed most fish fed on a large range of food items but relied heavily on shrimp, crabs/swimming-crabs, amphipods, mysids, polychaetes, ophiuroids, squids, and teleosteans. The species were classified into ten trophic groups. Shrimp were an important food source in the Santos bay and inner shelf, while ophiuroids were important prey for predators of the middle shelf. Many species relied on crabs/swimming-crabs during the summer, especially on the middle shelf. The spatial and temporal variability in food resource utilization by fish were related to the pattern of distribution and abundance of their prey. The predation on shrimp and crabs/swimming-crabs seems to be related to the water mass dynamics of the region. Intraspecific comparisons demonstrated that most of the species display spatial and/or temporal variation in their diet. The demersal ichtyofauna can also be divided into the more general categories of piscivores, nektonic invertebrate feeders, benthic invertebrate feeders and planktonic invertebrate feeders.
\end{abstract}

\section{RESUMO}

A variação temporal e espacial dos hábitos alimentares e dos grupos tróficos de peixes demersais abundantes na baía de Santos e plataforma continental adjacente foi investigada. As amostras foram obtidas em setembro de 2005 e março de 2006, utilizando-se rede de arrasto de fundo. A análise dos conteúdos estomacais de 2.328 exemplares de 49 espécies demonstrou que a maioria se alimentou de uma grande variedade de presas, destacando-se os camarões, caranguejos/siris, anfípodes, misidáceos, poliquetas, ofiuróides, lulas e teleósteos. De acordo com as presas principais, os peixes foram agrupados em dez grupos tróficos. Os camarões foram presas importantes na baía e plataforma interna, e os ofiuróides apenas na plataforma média. Caranguejos/siris tiveram grande importância na dieta de várias espécies durante o verão, em especial na plataforma média. A variação espacial e temporal na alimentação dos peixes esteve associada ao padrão de distribuição e abundância de suas presas. A ingestão de camarões e caranguejos/siris está, provavelmente, associada à dinâmica das massas de água na região. Comparações intraespecíficas demonstraram que a maioria das espécies apresenta variação espacial e/ou temporal na dieta. A ictiofauna demersal pode ser categorizada em grupos tróficos mais abrangentes: piscívoros, comedores de invertebrados nectônicos, comedores de invertebrados bentônicos e comedores de invertebrados planctônicos.

Descriptors: Diet, Stomach content, Marine fish, Teleostei, Elasmobranchii, Southeastern Brazil. Descritores: Dieta, Conteúdos estomacais, Peixes marinhos, Teleostei, Elasmobranchii, Sudeste do Brasil.

\section{INTRODUCTION}

The Baixada Santista is the main tourist coastal area of São Paulo State; its metropolitan region encompasses nine municipalities, with Santos
(419,400 inhab.) and São Vicente $(332,445$ inhab.) being the most heavily populated (IBGE, 2010). It constitutes a complex ecosystem with brackish and marine waters, islands, internal channels, estuaries, mangrove forests, and rainforest. Monitored by the 
State Environmental Agency (CETESB) since 1980, part of its marine zone was officially proclaimed as a Conservation Unit of Sustainable Use (SÃO PAULO, 2008a). It is an area subject to great environmental impacts, with many sources of anthropogenic pollution. The sewage disposal from the Santos and São Vicente estuaries promotes the eutrophication of Santos Bay and neighboring coastal waters, mainly during the summer. In addition to the port of Santos (the most important in Brazil), the industrial complex of Cubatão is responsible for the great volume of industrial effluents in the coastal region.

Marine and estuarine fisheries are an important economic activity; the landings in Santos were responsible for $\sim 60 \%$ of the total catch of São Paulo State in $2010(22,094.6 \mathrm{t})$ and $2011(20,931.9 \mathrm{t})$ (INSTITUTO DE PESCA, 2011, 2012). The sciaenids are the main target of the regional fishery, especially the white mouth, Micropogonias furnieri; the Jamaica weakfish, Cynoscion jamaicensis; and the king weakfish, Macrodon atricauda (VALENTINNI et al., 1991; ÁVILA-DA-SILVA et al., 2005).

Information on the diversity and temporal and spatial variation of the demersal ichthyofauna are available for the continental shelf located to the north of the area studied (ROSSI-WONGTSCHOWSKI; PAES, 1993; ROCHA; ROSSI-WONGTSCHOWSKI, 1998; MUTO et al., 2000). However, there are fewer data for the present study site. The estuarine complex of Santos-São Vicente represents one of the most important nursery grounds for the ichthyofauna, characterized by high fish diversity and abundance (PAIVA FILHO et al., 1987). The sciaenid fish are the most abundant family in Santos Bay all year round (GIANNINI; PAIVA FILHO, 1990). Human activities influence fish diversity and promote changes in the trophic interactions. For example, the replacement of long-lived piscivore fish by small planktivore fish and invertebrates in the overall fishery landings indicates the impact of fishing on the structure of marine food webs, affecting the abundance of top predators and promoting long-term changes in the number of species (PAULY et al., 1998; PAULY; WATSON, 2005).

Identification of food web linkages is a major goal in ecology because it provides basic information on trophic flows and the potential for interspecific interactions (REUM; ESSINGTON, 2008). Dietary data are essential to trace these linkages, enabling managers to cope with complex issues, such as biological control, conservation, and fishery management. Many studies have been conducted to clarify the trophic relationships of the coastal fish of Southeastern Brazil; however, the comprehensive studies carried out for the demersal fish assemblage off Ubatuba and São Sebastião shelf (north coast of São Paulo) showing the main energy pathway supporting fish production are worth mentioning (SOARES et al., 1992; SOARES et al., 1993; PIRES-VANIN et al., 1993; SOARES et al., 2008).

The present study was carried out in support of the project ECOSAN-subproject Trophodynamics, which assessed the food web of the Santos region using stable isotopes (SI) of carbon $\left(\delta^{13} \mathrm{C}\right)$ and nitrogen $\left(\delta^{15} \mathrm{~N}\right)$. While stable isotopes (SI) indicate the main sources of energy for consumers based on the assimilated food (PETERSON; FRY, 1987), stomach content data provide the taxonomic status of the prey ingested, and together with natural history information provide additional insights to support SI conclusions (PETERSON, 1999). We selected dominant species in the region as well as those representing important food habits. The species surveyed made up $92 \%$ and $85 \%$ of the abundance in Santos Bay (DIAS, J.F., pers. comm.) and continental shelf (DIAS et al., 2008), respectively. Of the 49 species analyzed, $8.2 \%$ are threatened with extinction (Atlantoraja cyclophora, Urophycis brasiliensis, Cynoscion jamaicensis, and Paralichthys patagonicus) and $14.3 \%$ (Lophius gastrophysus, Merluccius hubbsi, Macrodon atricauda, Micropogonias furnieri, Umbrina canosai, and two elasmobranchs - Rioraja agassizii and Rhinobatos percelens) are overexploited in São Paulo State (SÃO PAULO, 2008b). Therefore, understanding the biology of these species and their role in the ecosystem is critical for monitoring programs. Specifically, this study sought to identify the diet of dominant fish species of Santos Bay and the continental shelf and the trophic structure of the fish assemblage. The temporal and spatial variability of the trophic groups were also assessed.

\section{Material and Methods}

\section{Sampling}

The samples were collected during two research cruises conducted from 9 to 15 September (late austral winter, W) and 1 to 6 March 2006 (late austral summer, S) on board the Research Vessel Prof. W. Besnard (Oceanographic Institute, University of São Paulo) within the scope of the project "The Influence of the estuarine complex of the Baixada Santista on the adjacent continental shelf"s ecosystem (ECOSAN) - subproject Trophodynamics". Fish were collected using a bottom otter trawl with a $17-\mathrm{m}$ net (60-mm stretch-mesh in the body and sleeve and 25 $\mathrm{mm}$ at the cod end), and frozen at $-20^{\circ} \mathrm{C}$. Fifteen and thirty-minute hauls at the speed of 2 knots were carried out in Santos Bay and on the continental shelf, respectively. The fishing was conducted in two areas of Santos Bay (A1, A2; depth $=8.9$ to $11 \mathrm{~m}$ ) and six areas on the continental shelf, four of them located on the inner shelf (IS: A3, A4, A7, P9; depth = 
19.8 to $26.5 \mathrm{~m}$ ) and two on the middle shelf (MS: A5, A6; depth $=56$ to $57 \mathrm{~m}$ ) (Fig. 1). During the winter, the A5 area was not sampled due to poor weather conditions. All diet analyses were performed combining areas with similar depths; thus from now on these depth-areas will be referred to as regions. The trawling operation was repeated in some sites whenever fish samples were scarce for diet analyses. In the laboratory, each specimen was measured (total length, mm) and weighed (to the nearest $0.1 \mathrm{~g}$ ). For the elasmobranchs, the disc length was measured (from the tip of the snout to the posterior lobe of the pectoral fin). The stomachs were removed, preserved in formalin (10\%), and transferred to alcohol $(70 \%)$ for gut analysis.

The prey items were identified under stereomicroscope at different taxonomic levels, depending on the preservation of their bodies. Caridea and Dendrobranchiata decapods were referred to as shrimp, while Brachyura and Anomura were classified as crabs. For each prey category, we registered the occurrence (presence) and mass $(0.001 \mathrm{~g})$.

\section{Data analysis}

The prey were grouped into defined categories and weighed $(0.001 \mathrm{~g})$ according to season and region of sampling. The frequency of occurrence $\left(\mathrm{F}_{\mathrm{i}} \%\right.$, the number of stomachs containing a specific prey $_{i}$ expressed as a percentage of all stomachs examined for the species) and relative mass $\left(\mathrm{M}_{\mathrm{i}} \%\right.$, percentage of mass of prey $_{i}$ in relation to the total mass of all prey in the sample) of each prey category for each species were calculated in accordance with Hyslop (1980). Empty stomachs, as well as those with food remains difficult to identify at any taxonomic level, were excluded from the analysis. The importance of each prey category was evaluated through the Feeding Index (FI\%) of Kawakami; Vazzoler (1980), using mass instead of volume:

$$
\mathrm{FI}_{\mathrm{i}} \%=\mathrm{F}_{\mathrm{i}} \% \times \mathrm{M}_{\mathrm{i}} \% / \sum \mathrm{F}_{\mathrm{i}} \% \times \mathrm{M}_{\mathrm{i}} \% \times 100
$$

The FI\% was calculated for each species, by sampling region (Santos Bay, inner shelf, and middle shelf) and period (March and September).

The multivariate analysis was carried out on the total FI \% matrix, using the statistical package PRIMER 6 (CLARKE; WARWICK, 2001). Nine samples of each of nine species were excluded from this analysis. Prey categories with FI smaller than 5\% were pooled in the "other prey" category. Diet overlap among species (sample size > 5) was evaluated through cluster analyses (Q-mode), using the BrayCurtis similarity index and the Group Average method. The trophic groups were arbitrarily established at the limit of $50 \%$ of diet similarity; and to detect the average prey contribution to each group the SIMPER routine in PRIMER 6 was used.

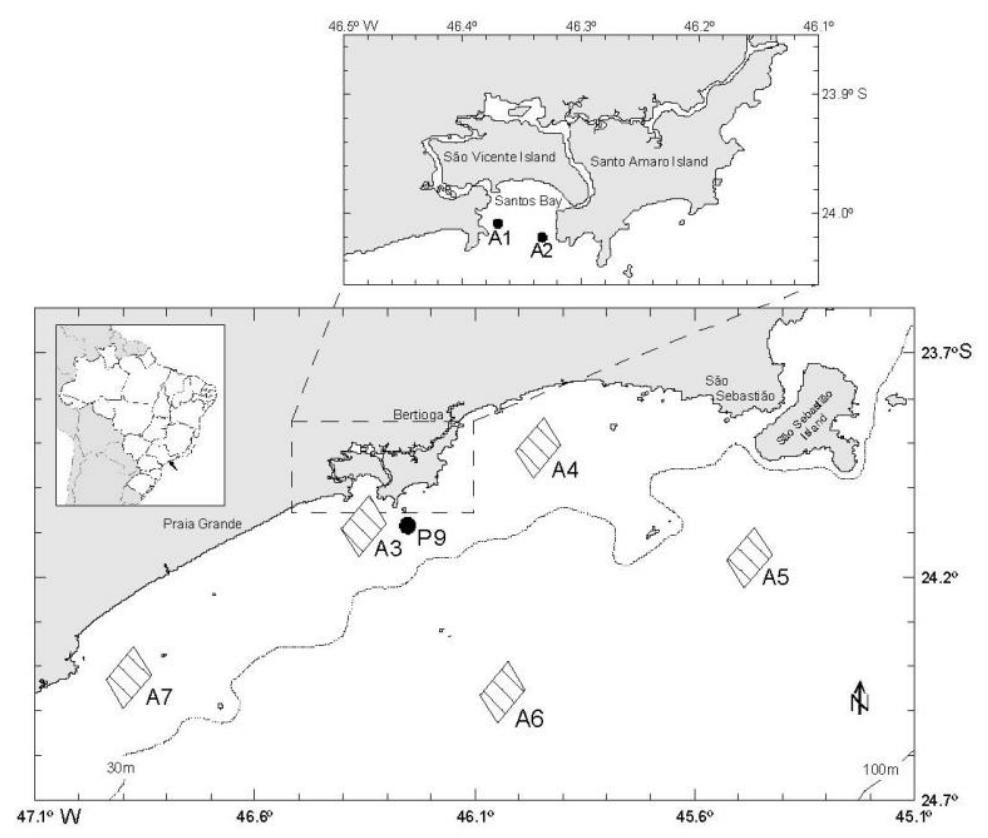

Fig. 1. Map showing the areas sampled in Santos Bay (upper frame) and adjacent continental shelf 


\section{Results}

A total of 2,328 individuals of 49 species (Table 1) were investigated for diet composition analysis, most of them collected in summer 2006 (70.5 $\%)$. The mean size of the species ranged from $5.6 \mathrm{~cm}$
(Pellona harroweri) to $45.7 \mathrm{~cm}$ (Zapteryx brevirostris) in winter 2005 (Fig. 2). Excluding Trichiurus lepturus $(107 \mathrm{~cm})$ and Paralichthys patagonicus $(56 \mathrm{~cm})$ because of their small sample sizes $(\mathrm{n}=1)$, in summer 2006 the mean size ranged from $8.9 \mathrm{~cm}$ (Anchoa filifera) to $53.4 \mathrm{~cm}$ (Z. brevirostris) (Fig. 3).

Table 1. Taxonomic list of fish species analyzed and respective codes. $\mathrm{B}=$ bay, IS $=$ inner shelf, $\mathrm{MS}=$ middle shelf.

\begin{tabular}{|c|c|c|c|}
\hline Order & Family & Species & Codes \\
\hline \multirow[t]{4}{*}{ Rajiformes } & \multirow[t]{2}{*}{ Rajidae } & Atlantoraja cyclophora & ATCY \\
\hline & & Psammobatis extenta & PSEX \\
\hline & \multirow[t]{2}{*}{ Rhinobatidae } & Rhinobatos percellens & RHPE \\
\hline & & Zapteryx brevirostris & ZABR \\
\hline \multirow[t]{4}{*}{ Clupeiformes } & Engraulidae & Anchoa filifera & ANFI \\
\hline & \multirow[t]{2}{*}{ Pristigasteridae } & Chirocentrodon bleekerianus & CHBL \\
\hline & & Pellona harroweri & PEHA \\
\hline & Clupeidae & Harengula clupeola & HACL \\
\hline Siluriformes & Ariidae & Cathorops spixii & CASP \\
\hline Ophidiiformes & Ophidiidae & Raneya brasiliensis & RABR \\
\hline \multirow[t]{2}{*}{ Gadiformes } & Phycidae & Urophycis brasiliensis & URBR \\
\hline & Merlucciidae & Merluccius hubbsi & MEHU \\
\hline Batrachoidiformes & Batrachoididae & Porichthys porosissimus & POPO \\
\hline Lophiiformes & Lophiidae & Lophius gastrophysus & LOGA \\
\hline \multirow[t]{3}{*}{ Scorpaeniformes } & Dactylopteridae & Dactylopterus volitans & DAVO \\
\hline & \multirow[t]{2}{*}{ Triglidae } & Prionotus punctatus & PRPU \\
\hline & & Prionotus nudigula & PRNU \\
\hline \multirow[t]{23}{*}{ Perciformes } & Serranidae & Serranus auriga & SEAU \\
\hline & \multirow[t]{4}{*}{ Carangidae } & Chloroscombrus chrysurus & $\mathrm{CHCH}$ \\
\hline & & Conodon nobilis & CONO \\
\hline & & Selene setapinnis & SESE \\
\hline & & Trachurus lathami & TRLA \\
\hline & \multirow[t]{2}{*}{ Gerreidae } & Diapterus rhombeus & DIRH \\
\hline & & Eucinostomus argenteus & EUAR \\
\hline & Haemulidae & Orthopristis ruber & ORRU \\
\hline & \multirow[t]{12}{*}{ Sciaenidae } & Ctenosciaena gracilicirrhus & CTGR \\
\hline & & Cynoscion jamaicensis & CYJA \\
\hline & & Larimus breviceps & LABR \\
\hline & & Isopisthus parvipinnis & ISPA \\
\hline & & Nebris microps & NEMI \\
\hline & & Macrodon atricauda & MAAN \\
\hline & & Menticirrhus americanus & MEAM \\
\hline & & Micropogonias furnieri & MIFU \\
\hline & & Paralonchurus brasiliensis & PABR \\
\hline & & Stellifer brasiliensis & STBR \\
\hline & & Stellifer rastrifer & STRA \\
\hline & & Umbrina canosai & UMCA \\
\hline & \multirow[t]{2}{*}{ Mullidae } & Mullus argentinae & MUAR \\
\hline & & Upeneus parvus & UPPA \\
\hline & Percophidae & Percophis brasiliensis & PEBR \\
\hline \multirow[t]{7}{*}{ Pleuronectiformes } & Trichiuridae & Trichiurus lepturus & TRLE \\
\hline & \multirow{6}{*}{ Paralichthyidae } & Etropus crossotus & ETCR \\
\hline & & Etropus longimanus & ETLO \\
\hline & & Paralichthys isocelles & PAIS \\
\hline & & Paralichthys patagonicus & PAPAT \\
\hline & & Paralichthys triocellatus & PATR \\
\hline & & Xystreurys rasile & XYRA \\
\hline \multirow[t]{2}{*}{ Tetraodontiformes } & Monacanthidae & Stephanolepis hispidus & STHI \\
\hline & Tetraodontidae & Lagocephalus laevigatus & LALA \\
\hline
\end{tabular}


Winter 2005

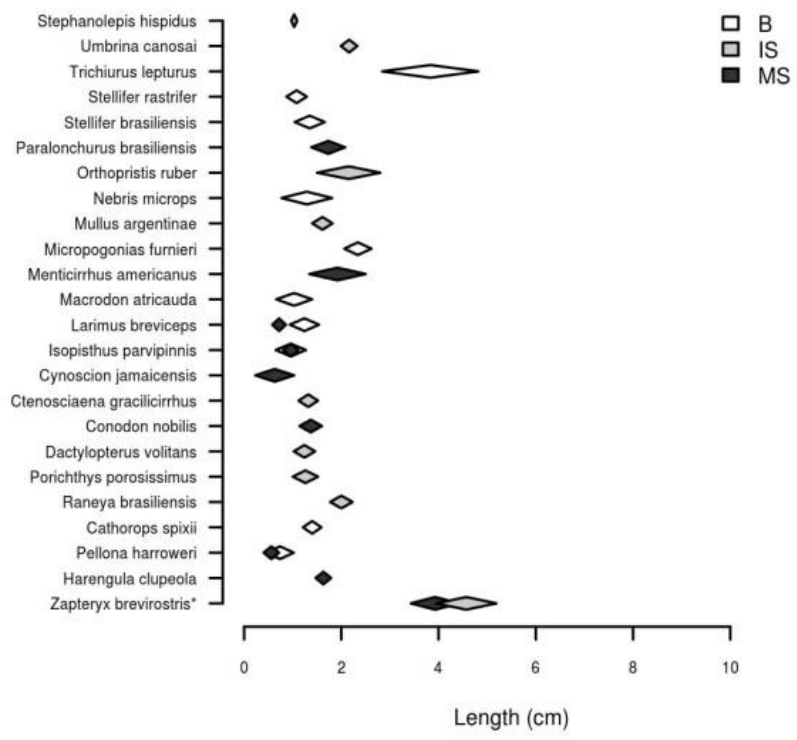

Fig. 2. Mean length ( \pm standard deviation) of fish species analyzed in Santos Bay (white diamond), inner shelf (gray diamond), and middle shelf (black diamond) during the winter 2005. * disc length

Summer 2006

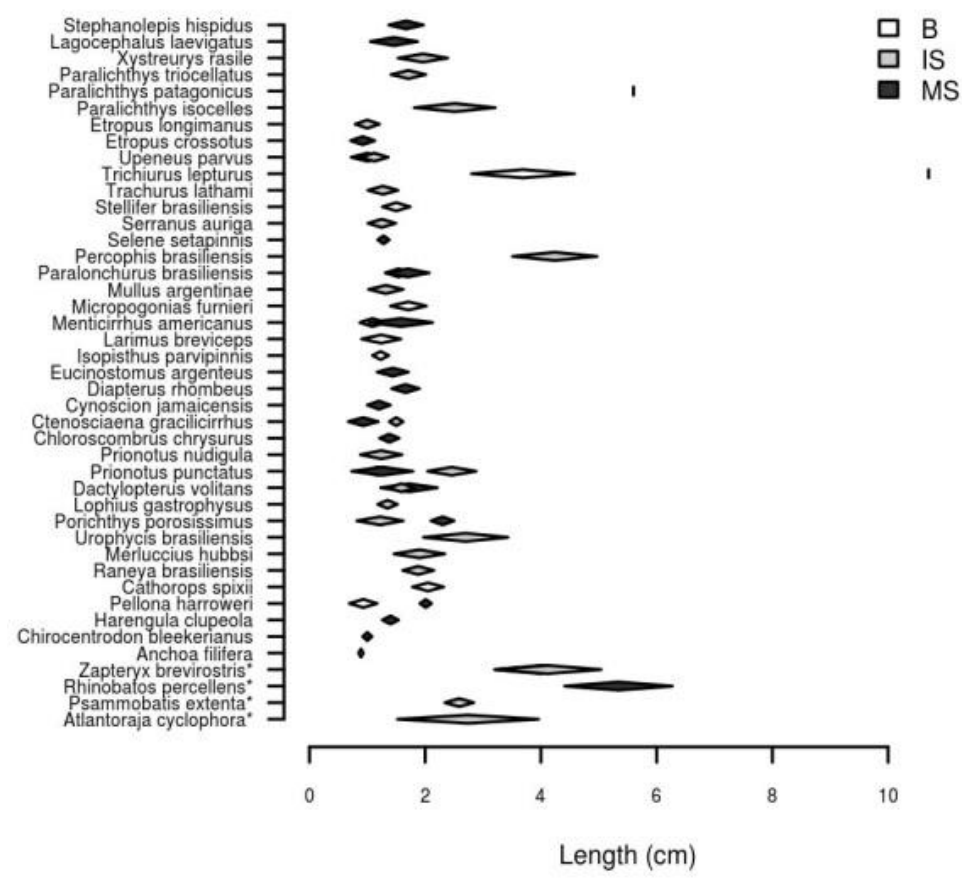

Fig. 3. Feeding index (\%) of prey items of fish species sampled in Santos Bay, inner shelf, and middle shelf during the winter 2005. Size of the sample is indicated in brackets. See table 1 for species codes. 

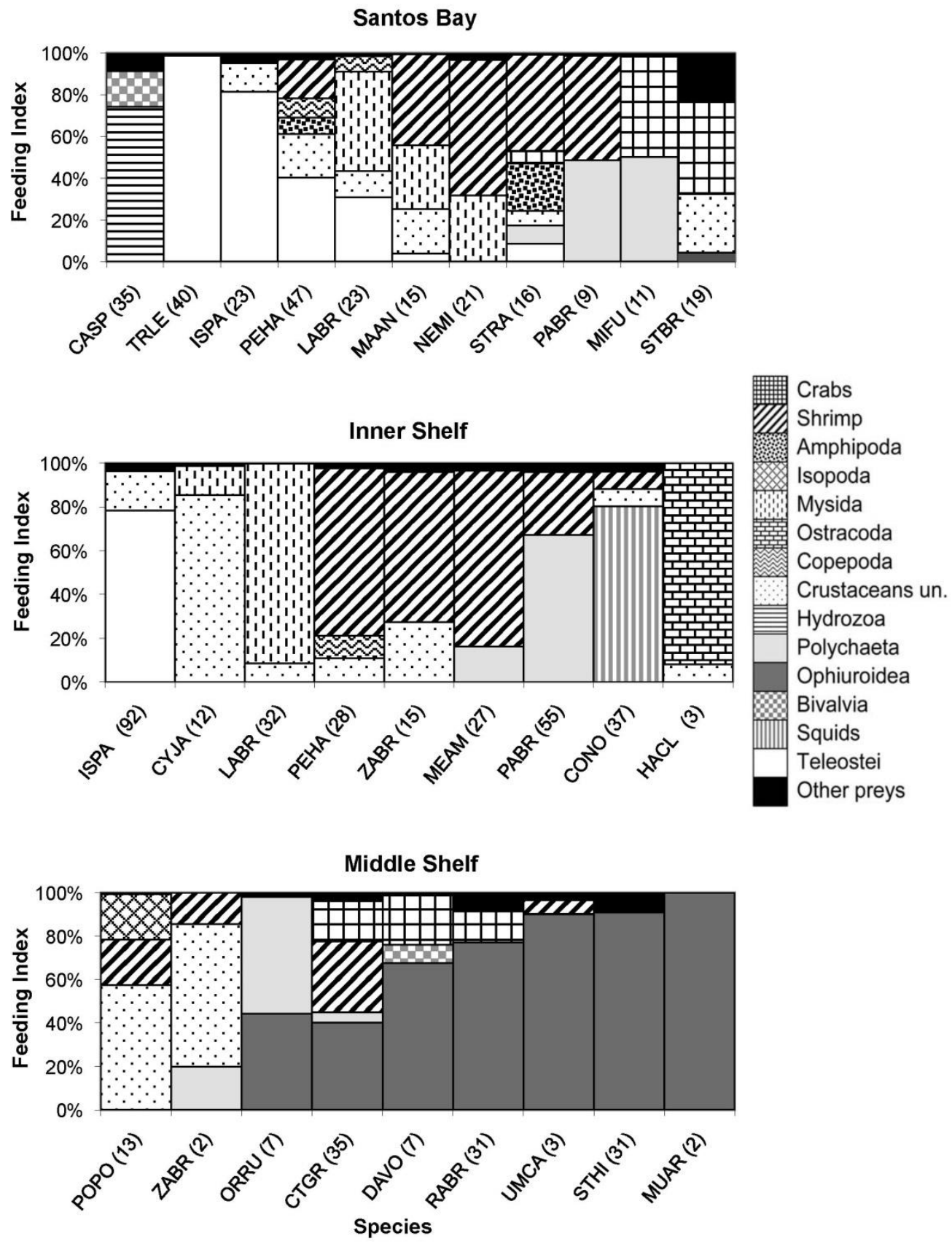

Fig. 4. Feeding index (\%) of prey items of fish species sampled in Santos Bay, inner shelf and middle shelf during the winter 2005. Size of the sample is indicated in brackets. See table 1 for species codes 

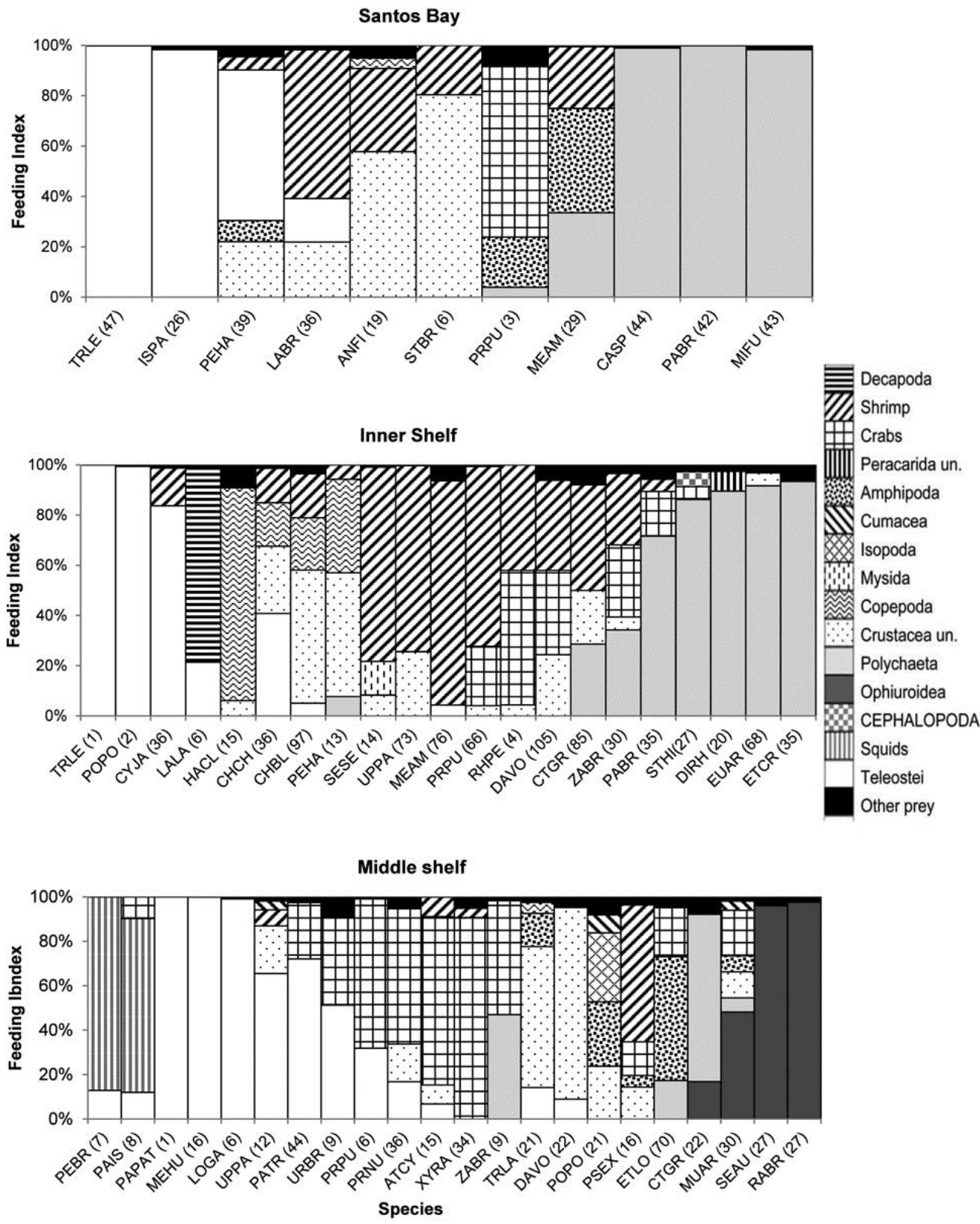

Fig. 5. Feeding index (\%) of prey items of fish species sampled in Santos Bay, inner shelf and middle shelf during the summer 2006. Size of the sample is indicated in brackets. See table 1 for species codes

Diet

The taxonomic list of the prey identified in the stomach contents and the frequency of occurrence and relative mass of the main prey groups are presented (Appendix). Because of their importance in the diet, the following prey categories were used in the cluster analysis and figures: Hydrozoa, Polychaeta,
Ophiuroidea, Crustacea unidentified (un.), Copepoda, Peracarida un., Amphipoda, Cumacea, Isopoda, Mysida, Decapoda un., shrimp, crabs, Cephalopoda un., Bivalvia, squids, and Teleostei. The remaining prey categories were grouped into "other items".

On the whole, during the winter the diet compositions of the fish species in Santos Bay (B) were closely similar to those of the inner shelf (IS) 
(Fig. 4). Teleosteans, shrimp, polychaetes, and mysids were the predominant prey in both areas. Crabs, amphipods, hydrozoans and bivalves contribute greatly to the diet of some species of the bay, while copepods made up a small part of the diet of two species. Squids were the main food for one species of the IS. Although ostracods represented $92 \%$ (FI) of the diet of Harengula clupeola, the sample size was too small to characterize the diet of the species. On the middle shelf (MS), ophiuroids were prominent in the diet of many species, in addition to shrimp, crabs, and polychaetes. Isopods were important food for Porichthys porosissimus, while bivalves made a minor contribution to the diet of Dactylopterus volitans.

During summer 2006, the diet composition of the fish assemblage was more diversified. Teleosteans, polychaetes, and shrimp were important prey in Santos Bay and IS; crabs and copepods were especially important for some species in the IS (Fig. 5). For some species of the bay (Menticirrhus americanus, Prionotus punctatus, and Pellona harroweri), amphipods were also important food items. In the MS, Teleosteans and crabs were the most exploited prey. Ophiuroids, squids, polychaetes, amphipods, isopods, and shrimp contributed greatly to the diets of some species. Cumaceans and copepods were of minor importance for the species of the middle shelf.

Trophic Groups (TG)

The cluster analysis showed 10 major trophic groups for the 46 fish species examined (Table 3, Fig. 6): G1 = teuthophagous (squids); G2 = crustacean unidentified (un.) and shrimp feeders; G3 = shrimp and crustacean (un.) feeders; G4 = shrimp, polychaete, and crustacean (un.) feeders; G5 = mysid and crustacean (un.) feeders; G6 = crab and crustacean (un.) feeders; G7 = piscivores (teleosteans); G8 = ophiuroid and crab feeders; G9 = polychaete feeders; G10 = amphipod and polychaete feeders. The G2 and G3 groups differed in their contribution of shrimp and crustacean unidentified to the diet. The prey contributions $(\%)$ to the species grouping within a specific TG are represented in Table 2. Four sample species were not included in any group: Cathorops spixii $\left(\mathrm{B}_{\text {winter }}\right)$ feeding on hydrozoans, Harengula clupeola ( $\left.\mathrm{IS}_{\text {summer }}\right)$ on copepods, Lagocephalus laevigatus $\left(\mathrm{IS}_{\text {summer }}\right)$ on decapods unidentified, and Porichthys porosissimus $\left(\mathrm{MS}_{\text {summer }}\right)$ on crustacean unidentified, shrimp, and isopods (Fig. 6).

Shrimp (G3), teleostean (G7), and polychaete (G9) feeder groups included most of the fish species, with 12,10 , and 10 , respectively (Table 3, Figure 6). The G8 group (ophiuroid and crab feeders) was exclusive to the MS. The G5 (mysid feeders) occurred only during the winter, the G10 (amphipod and polychaete feeders) during the summer.

\section{Specific Spatio-Temporal Comparisons}

Spatial comparisons performed for winter samples showed that Isopisthus parvipinnis, Larimus breviceps and Paralonchurus brasiliensis of the bay and IS stayed in the same trophic group (TG), while Pellona harroweri moved from the piscivore group (G7) in the bay to shrimp and crustacean unidentified (un.) feeder group (G3) on the IS. In the summer, most of the species $(87.5 \%)$ occurring in at least two areas displayed contrasting diets; with the exception of Paralonchurus brasiliensis that fed on polychaetes in both bay and IS (Table 3 ).

Specific seasonal dietary differences in the bay occurred for four species (50\%), while three piscivores (I. parvipinnis, P. harroweri and Trichiurus lepturus) and one polychaete feeder (Micropogonias furnieri) stayed in the same TG. Among the five species of the IS and four of the MS, only Menticirrhus americanus (IS) and Raneya brasiliensis (MS) exploited the same prey type in both periods (Table 3).

\section{DisCUSSION}

The fish assemblage of the Santos region used a broad range of food sources, comprising nektonic, planktonic, and benthic organisms of the infauna, epifauna, and suprabenthos. The most representative prey were decapods (shrimp and crabs), amphipods, mysids, copepods, squids, polychaetes, ophiuorids, and bony fish. The coastal demersal fish of Santos feed on similar food resources to those exploited by the fish community of the soft bottom shelf worldwide. For example, in the tropical bay of Thailand (depth $<5 \mathrm{~m}$ ), the fish community (28 species) feed on a variety of prey, especially on calanoid copepods and shrimp; however, the feeding variability is influenced by monsoon-seasons and substrate type (sandy or muddy bottom) (HAJISAMAE; IBRAHIM, 2008). In addition to copepods and shrimp, fish and gammaridean amphipods are also included among the main food items of 48 bottom fish species sampled in the coastal areas (mean depths $=12.3$ to $19.8 \mathrm{~m}$ ) of Thailand (HAJISAMAE, 2009). On the continental shelf off Mexico, decapods are the main prey for most demersal fish from depths of 20 to $80 \mathrm{~m}$, in addition to mollusks, and fish (PÉREZ-ESPAÑA et al., 2005). Off the west coastal of Australia (depth $=5-35 \mathrm{~m}$ ), polychaetes, crustaceans, mollusks, echinoderms, and fish represent the major prey for 18 benthic fish (PLATELL; POTTER, 2001). Most of the benthic fish 
(102 species) off the Southeastern Australia shelf feed on benthic prey; pelagic invertebrates and fish are important for some species (BULMAN et al., 2001). Off the continental shelf of Colombia, the main food types for 30 species are benthic crustaceans (crabs, shrimp, and stomatopods) and bony fish (LÓPEZPERALTA; ARCILA, 2002). Macrobenthic invertebrates (amphipods, decapods, and polychaetes) are the main food items for nine dominant fish of the outer shelf of New Jersey and Delaware (US), in addition to fish, cephalopods, and pelagic invertebrates (SEDBERRY et al., 1979). A large scale study based on a comprehensive literature review covering 60 fish species of the Southeastern shelf of the United States showed three dominant trophic guilds: piscivores, carnivores and browsers (MARANCIK; HARE, 2007). The carnivores feed mainly on fish and invertebrates, while browsers on bryozoans, algae, poriferans, hydrozoans, and anthozoans.

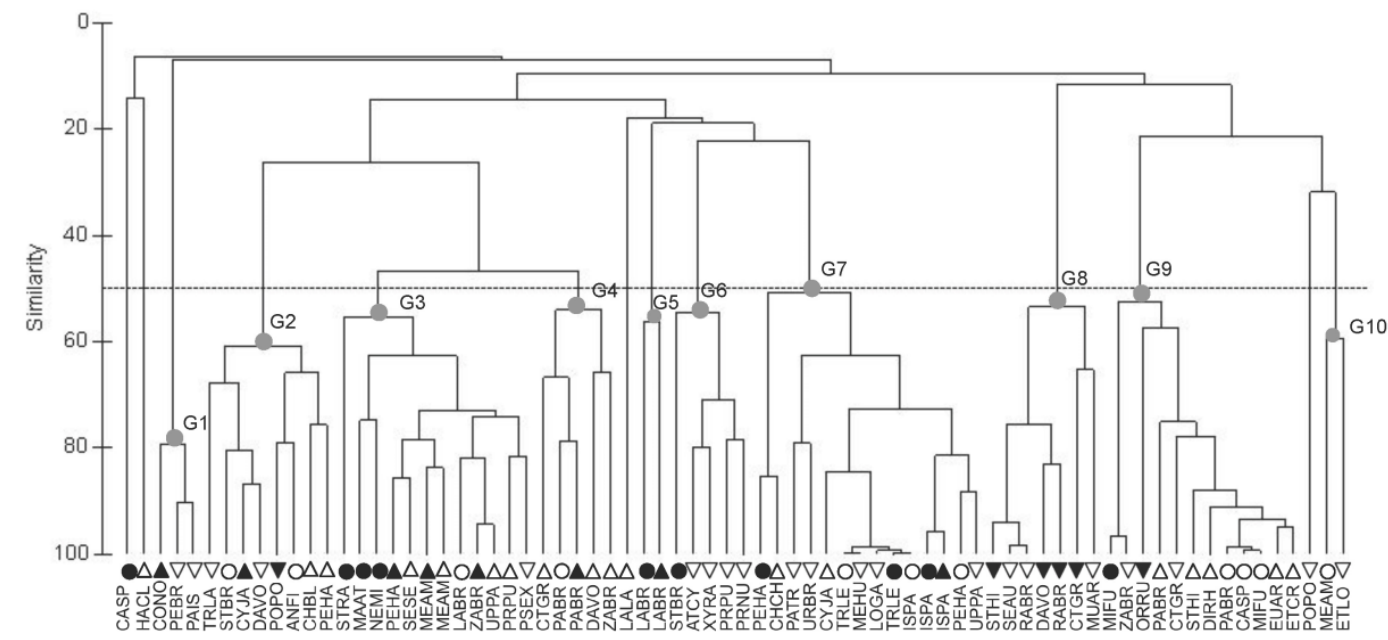

Samples

Fig. 6. Dendrogram showing the trophic groups of fish sampled in Santos Bay (circle), inner shelf (triangle) and middle shelf (inverted triangle) during the winter ( $\mathrm{W}=$ September 2005, closed symbols) and summer ( $\mathrm{S}=$ March 2006, open symbols). Trophic groups: G1 = teuthophagous; G2 = crustacean unidentified (un.) and shrimp feeders; G3 = shrimp and crustacean (un.) feeders; G4 = shrimp, polychaete, and crustacean (un.) feeders; G5 = mysid and crustacean (un.) feeders; G6 = crab and crustacean (un.) feeders; G7 = piscivores; G8 = ophiuroid and crab feeders; G9 = polychaete feeders; G10 = amphipod and polychaete feeders. See table 1 for fish species codes

Table 2. Results of the SIMPER analysis showing the average prey contribution (cumulative $90 \%$ ) to each trophic group of the dendrogram. un. $=$ unidentified

\begin{tabular}{|c|c|c|c|c|c|c|c|c|c|}
\hline \multirow[b]{2}{*}{ TROPHIC GROUPS } & \multicolumn{9}{|c|}{ MAIN PREY } \\
\hline & Squids & Crustacean un. & Shrimp & Crabs & Mysida & Amphipoda & Polychaeta & Ophiuroidea & Teleostei \\
\hline G1 & 95.2 & & & & & & & & \\
\hline G2 & & 87.8 & 7.4 & & & & & & \\
\hline G3 & & 8.3 & 87.0 & & & & & & \\
\hline G4 & & 5.3 & 51.3 & & & & 33.8 & & \\
\hline G5 & & 15.0 & & & 84.5 & & & & \\
\hline G6 & & 5.2 & & 86.8 & & & & & \\
\hline G7 & & & & & & & & & 91.8 \\
\hline G8 & & & & 7.1 & & & & 88.7 & \\
\hline G9 & & & & & & & 95.1 & & \\
\hline G10 & & & & & & 69.8 & 29.3 & & \\
\hline
\end{tabular}


Table 3. Summary of species composition, main prey, and number of species (N) included in each trophic group. See table 1 for species codes. un. $=$ unidentified

\begin{tabular}{|c|c|c|c|c|c|c|c|c|}
\hline \multirow[b]{2}{*}{$\begin{array}{l}\text { Trophic } \\
\text { groups }\end{array}$} & \multirow[b]{2}{*}{ Main prey } & \multicolumn{3}{|c|}{ W I N T E R 2005} & \multicolumn{4}{|c|}{ S UMM E R 2006} \\
\hline & & Bay & Inner shelf & Middle shelf & Bay & Inner shelf & Middle shelf & $\mathbf{N}$ \\
\hline G1 & Squid & & $\mathrm{CONO}$ & & & & PEBR, PAIS & 3 \\
\hline G2 & $\begin{array}{l}\text { Crustacean un., } \\
\text { shrimp }\end{array}$ & & CYJA & POPO & $\begin{array}{l}\text { ANFI, } \\
\text { STBR }\end{array}$ & CHBL, PEHA & DAVO, TRLA & 8 \\
\hline G3 & $\begin{array}{l}\text { Shrimp, crustacean } \\
\text { un. }\end{array}$ & $\begin{array}{l}\text { MAAT, } \\
\text { NEMI, } \\
\text { STRA }\end{array}$ & $\begin{array}{l}\text { MEAM, } \\
\text { PEHA, } \\
\text { ZABR }\end{array}$ & & LABR & $\begin{array}{l}\text { MEAM, SESE, } \\
\text { UPPA, PRPU }\end{array}$ & PSEX & 12 \\
\hline G4 & $\begin{array}{l}\text { Shrimp, Polychaetes, } \\
\text { crustacean un. }\end{array}$ & PABR & PABR & & & $\begin{array}{l}\text { DAVO, CTGR, } \\
\text { ZABR }\end{array}$ & & 4 \\
\hline G5 & $\begin{array}{l}\text { Mysida, crustacean } \\
\text { un. }\end{array}$ & LABR & LABR & & & & & 1 \\
\hline G6 & Crabs, crustacean un. & STBR & & & & & $\begin{array}{l}\text { ATCY, PRPU, } \\
\text { PRNU, XYRA }\end{array}$ & 5 \\
\hline G7 & Teleostei & $\begin{array}{l}\text { ISPA, } \\
\text { PEHA, } \\
\text { TRLE }\end{array}$ & ISPA & & $\begin{array}{l}\text { ISPA, } \\
\text { PEHA, } \\
\text { TRLE }\end{array}$ & $\mathrm{CHCH}, \mathrm{CYJA}$ & $\begin{array}{l}\text { LOGA, MEHU, } \\
\text { PATR, UPPA, } \\
\text { URBR }\end{array}$ & 10 \\
\hline G8 & Ophiuroidea, crabs & & & $\begin{array}{l}\text { CTGR, DAVO, } \\
\text { RABR, STHI }\end{array}$ & & & $\begin{array}{l}\text { MUAR, RABR, } \\
\text { SEAU }\end{array}$ & 7 \\
\hline G9 & Polychaetes & MIFU & & ORRU & $\begin{array}{l}\text { CASP, } \\
\text { MIFU, } \\
\text { PABR }\end{array}$ & $\begin{array}{l}\text { DIRH, ETCR, } \\
\text { EUAR, PABR, } \\
\text { STHI }\end{array}$ & CTGR, ZABR & 10 \\
\hline G10 & $\begin{array}{l}\text { Amphipoda, } \\
\text { Polychaetes }\end{array}$ & & & & MEAM & & ETLO & 2 \\
\hline TOTAL & & 6 & 6 & 3 & 5 & 5 & 8 & \\
\hline
\end{tabular}

The diet composition of the species analyzed in the Santos region was consistent with that found for the Southeastern region of Brazil (SOARES, 1989; SOARES et al., 1992; MUTO et al. 2001; SOARES; VAZZOLER, 2001; CORRÊA et al., 2005; CARVALHO; SOARES, 2006; VERA; SOARES, 2008; MARION et al., 2011; MUTO; SOARES, 2011), though the prey contributions to the diet are different for some species.

On the northern continental shelf off São Paulo, the demersal fish community made up six trophic groups: pelagic piscivores; benthic piscivores; fish and/or pelagic prey feeders; fish and benthic invertebrate (shrimp) feeders; benthic invertebrate feeders (brachyurans, shrimp, and amphipods); benthic invertebrate feeders (polychaetes, ophiuroids, and infaunal crustaceans) (SOARES et al., 2008). Similar results were obtained in the present study.

The trophic groups found in the Santos region can be further categorized as: a) piscivores, b) nektonic invertebrate feeders, c) benthic invertebrate feeders, and d) planktonic invertebrate feeders. Assuming that the unidentified crustaceans of the G2 group are remains of those represented in the stomach contents of each species, Chirocentrodon bleeckerianus ( $\mathrm{IS}_{\text {summer }}$ ), Pellona harroweri $\left(\mathrm{IS}_{\text {summer }}\right)$, Trachurus lathami ( $\left.\mathrm{MS}_{\text {summer }}\right)$, and Anchoa filifera $\left(\mathrm{B}_{\text {summer }}\right)$, together with Harengula clupeola $\left(\mathrm{IS}_{\text {summer }}\right)$, would compose the planktonic invertebrate feeders group, since copepods and the pelagic shrimp sergestid and luciferid (OMORI, 1975) are the dominant food items for those species (pers. data, unpublished; CARVALHO; SOARES, 2006; MUTO et al., 2008). Sergestids were the major shrimp in the diet of Selene setapinnis (G3), Macrodon atricauda (G3), and Nebris microps (G3) (pers. data), while copepods were also important food items for Chloroschombrus chrysurus $\left(\mathrm{SI}_{\text {summer }}\right)$, showing the pelagic habits of those species. In contrast, most of the shrimp feeder fish of the continental shelf fed on the small carideans Leptochela and processids (pers. data). The oblique mouth of Larimus breviceps suggests that the mysids consumed by the species are of pelagic habits, as found in Santos Bay and at Perequê Beach, where L. breviceps feeds on sergestid shrimp and mysids (RODRIGUES; MEIRA, 1988). Mysids are more abundant on and just above the sea floor; however, in coastal waters, they perform a diel vertical migration, ascending and dispersing into the water column during the night (MURANO, 1999). The unidentified crustaceans consumed by Cynoscion jamaicensis during the winter might have been mysids, therefore this species belongs to the same group as L. breviceps.

The other species of the G2 group, Porichthys porosissimus $\left(\mathrm{MS}_{\text {winter }}\right)$, could be classified as benthic invertebrate feeders, similar to those specimens from the $\mathrm{MS}_{\text {summer }}$. The two individuals from $\mathrm{IS}_{\text {summer }}$ fed on teleosteans; however, bigger specimens tend to rely on fish while the smaller ones on crustaceans (MUTO, 2004). Indeed, the mean size of $P$. porosissimus of the IS was $23.0 \mathrm{~cm}$ in contrast to $12.0 \mathrm{~cm}$ for specimens from the MS. Also, Stellifer brasiliensis of G2 group is probably feeding on shrimp (G3), as found by Rodrigues; Meira (1988). Although in summer Dactylopterus volitans fed on crabs and 
shrimp on the IS, the unidentified crustaceans consumed by this species on the MS might be crabs because shrimp were not well represented in the diet of most species in the deeper area in this period, suggesting the low availability of that prey.

Intraspecific spatial comparisons showed that during the winter the species tended to feed on the same prey in the bay and IS; while in the summer, most of the species underwent spatial dietary shifts, feeding on shrimp on the IS and on different prey in the bay or MS. Temporal differences were prominent for most species, except for some sciaenids (Isopisthus parvipinnis, Menticitthus americanus, Micropogonias furnieri), Trichiurus lepturus, and Raneya brasiliensis. The results highlight the complexity and plasticity of the trophic relationships of the demersal ichthyofauna in the system, where variability occurred at species and community levels suggesting that different species or population strata can have a particular trophic niche in a variable combination of time/space dimensions. The trophic plasticity allows fish species to cope with the availability of their preferred prey in a variable environment (GERKING, 1994).

The spatial and temporal variations of the trophic structure of the ichthyofauna of Santos can be partially explained by the differential distribution of fish species as well as of their prey. The oceanographic structure of the region was typical for winter and summer seasons in the South Brazilian Bight, with the interaction of three water masses: the warm Coastal Water (CW; $\left.\mathrm{T}>20^{\circ} \mathrm{C}, \mathrm{S}>36.40\right)$, a mixture of continental freshwater and marine waters; the oligotrophic Tropical Water (TW; temperature < $20^{\circ} \mathrm{C}$, salinity > 36.40); and the nutrient enriched South Atlantic Central Water (SACW; T < $20^{\circ} \mathrm{C}, \mathrm{S}<$ 36.40) (CASTRO FILHO; MIRANDA, 1998). Typically, the inner shelf is occupied by the $\mathrm{CW}$ and the water column is vertically homogeneous due to a mixing process induced by wind stress and tidal shear. The waters on the inner and middle shelf are separated by a bottom thermal front that moves seasonally, located 10 to $20 \mathrm{~km}$ from the coast during the austral summer and $40-50 \mathrm{~km}$ offshore during the winter. During the summer, the water column of the middle shelf is stratified due to the presence of the cold SACW on the bottom and the CW (near the coast) and TW (offshore) in the upper layer (CASTRO FILHO: MIRANDA, 1998). In the Santos region, the surface water was warmer and the intrusion of the SACW was stronger during the summer 2006, and the mixing of the SACW with CW occurred near the coast (PIRESVANIN et al., 2007).

The dynamics of the nutrient poor water masses (CW and $\mathrm{TW})$ and the nutrient enriched SACW play an important role in the distribution of fish (ROSSI-WONGTSCHOWSKI; PAES, 1993; ROCHA; ROSSI-WONGTSCHOWSKI, 1998;
MUTO et al., 2000; ROSSI-WONGTSCHOWSKI et al., 2008) and invertebrates (PIRES-VANIN, 1993; PIRES-VANIN, 2008a) on the shelf. For instance, the fish species Paralichthys patagonicus, Serranus auriga, Merluccius hubbsi, Urophycis brasiliensis, and Lophius gastrophysus, that usually occupy the outer domain of the shelf, follow the SACW movement toward the shore during the summer (ROSSI-WONGTSCHOWSKI; PAES, 1993). The abundance of the swimming crab Portunus spinicarpus and the shrimp Xiphopenaeus kroyeri alternates according to the water masses, the former is related to the SACW frontal zone, and the later to the warm CW (PIRES, 1992). The seasonal pattern of prey availability is reflected in the food resources used by predators, modifying the trophic structure of the planktonic and demersal communities (PIRESVANIN et al., 1993).

Changes in the species trophic guild may depend not only on biological features but also on the spatio-temporal changes in the ecological interactions between species (CARRASSÓN; CARTES, 2002). Within the scope of the project ECOSAN, the benthic megafauna of Santos Bay was sampled monthly during 2005, with higher abundances between January and July. In March and September the shrimp Xiphopenaeus kroyeri was the dominant species, followed by the swimming crabs Callinectes danae and C. ornatus (PIRES-VANIN et al., 2008b). Previous results in the study area showed that polychaetes $\quad(\mathrm{W}=$ winter $=69 \%, \quad \mathrm{~S}=$ summer $=88 \%)$, mollusks $(\mathrm{W}=17 \%, \mathrm{~S}=5 \%)$, and crustaceans ( $\mathrm{W}=12 \%$, $\mathrm{S}=3 \%$ ) were the dominant benthic macrofauna (HEITOR; TOMMASI, 2001).

On the continental shelf, crustaceans were the dominant megafaunal group in both seasons; penaeid shrimp made up $66 \%$ of the total abundance during the winter 2005, followed by brachyurans $(16 \%)$ and asteroids (9\%). In the summer 2006, brachyurans $(61 \%)$, asteroids $(19 \%)$, and penaeid shrimp (5\%) were the most abundant groups. The macrofauna was mostly represented by polychaetes (59\%), amphipods (14\%), and ophiuroids (7\%) during the winter; while in the summer, polychaetes, bivalves, and amphipods made up 54\%, 12\%, and 10\% of the total abundance, respectively (PIRES-VANIN et al., 2006; PIRES-VANIN et al., 2007).

As a whole, in both periods shrimp were an important food source in the shallower areas (bay and inner shelf) and ophiuroids on the middle shelf. In Ubatuba and São Sebastião, located to the north of Santos, there is high correlation between fish biomass, especially sciaenids, and shrimp biomass (SOUZA et al., 2008). The dietary analysis of 33 fish of Santos Bay and Perequê beach showed that shrimp, polychaetes, and teleosteans were the main food resource ingested. However, although Xiphopenaeus 
kroyeri was consumed by many species, Acetes americanus (sergestid) was the major shrimp in the stomach contents (RODRIGUES; MEIRA, 1988), as found in our study.

Polychaetes were an abundant food resource in all areas and seasons investigated, thus the greater number of fish species using that resource in the summer may have resulted from the greater sampling effort expended in that season instead of being due to the scarcity of this prey during the winter. Crabs were mainly consumed during the summer, as well as copepods. The considerable contribution of crabs for the fish on the shelf in this period might be related to the higher abundance of these prey items associated with the water mass dynamics. During the summer, the most abundant brachyurans on the shelf were Portunus spinicarpus, P. spinimanus, and Leurocyclus tuberculosus; the former predominated on the MS (PIRES-VANIN et al., 2007). The distribution patterns of $P$. spinicarpus and $X$. kroyeri on the shelf are linked to the presence of different water masses; the former is associated with the cold front of South Atlantic Central Water and the latter with the warm Coastal Water (PIRES, 1992).

In the shelf ecosystem of northern São Paulo phytoplankton is the main source of organic matter for the benthos during the summer, with some contribution from salp faecal pellets resulting from intensive grazing. During the winter, detritus is the main fuel for the benthic trophic web; the subsurface invertebrates become available for predators due to the suspension of bottom sediments during this period (PIRES-VANIN et al., 1993). On the continental shelf of Santos, according to the main food resources used by the species, detritus was the major trophic pathway supporting the fish assemblage. The trophic linkage to phytoplankton seems to be stronger in the summer and in the shallower area, as evidenced by the presence of species that feed on pelagic invertebrates (copepods, sergestid shrimp, and squids), and pelagic fish (MARTINS et al, 2005; SOARES et al., 2008; MUTO; SOARES, 2011).

In the present study we have not addressed the ontogenetic shift in the diet; this is, however, an important variable to be investigated in future studies since size-related dietary change is widely documented (GARRISON; LINK, 2000a; PLATELL; POTTER, 2001; HAJISAMAE, 2009), with many species occurring in different trophic guilds across their life history (GARRISON; LINK, 2000b).

In conclusion, the trophic structure of the demersal ichthyofauna of the Santos region is very dynamic, changing over time and space (depth). The pattern of distribution of fish species and their prey dictated by the oceanographic conditions seems to influence the species composition of trophic groups and the diet of many species.

\section{ACKNOWLEDGMENTS}

Financial support for the project ECOSAN was provided by the State of São Paulo Research Foundation (FAPESP/PRONEX $n^{\circ}$ 2003/09932-1). This study is part of the post-doc project of Elizabeti Y. Muto sponsored by FAPESP (Proc. n. 06/56974-0) and CNPq (Proc. n. 150 422/2005-9). Scientific Initiation fellowships were granted to Arantes, L.P.L. (FAPESP Proc. n. 2007/03252-0), Chalom, A. and Coelho, L.I. (PIBIC/CNPq/USP). The authors are grateful to the crew of the RV Prof. W. Besnard for their support with the fish collection. We wish to express our thanks to Prof. Dr Edmundo Nonato and Dr Monica Petti (IO-USP) for their help in identifying some invertebrates, as well as to the two anonymous reviewers for their valuableon comments on the manuscript.

\section{REFERENCES}

ÁVILA-DA-SILVA, A. O.; CARNEIRO, M. H.; MENDONÇA, J. T.; SERVO, G. J. M.; BASTOS, G. C. C.; OKUBO-DA-SILVA, S.; BATISTA, P. A. Produção pesqueira marinha do Estado de São Paulo no ano 2004. São Paulo: Instituto de Pesca, 2005. p. 1-40. (Série Relatórios Técnico; n. 20).

BUlMAN, C., ALTHAUS, F.; HE, X.; BAX, N. J.; WILLIAMS, A. Diets and trophic guilds of demersal fishes of the south-eastern Australian shelf. Mar. Freshwater Res., v. 52, p. 537-548, 2001.

CARRASSÓN, M.; CARTES, J. E. Trophic relationships in a Mediterranean deep-sea fish community: partition of food resources, dietary overlap and connections within the benthic boundary layer. Mar. Ecol.: Prog. Ser., v. 241, p. 41-55, 2002.

CARVALHO, M. R.; SOARES, L. S. H. Diel feeding pattern and diet of rough scad Trachurus lathami Nichols, 1920 (Carangidae) from the southwestern Atlantic. Neotrop. Ichthyol., v. 4, n. 4, p. 419-426, 2006.

CASTRO FILHO, B. M.; MIRANDA, L. B. Physical oceanography of the western Atlantic continental shelf located between $4^{\circ} \mathrm{N}$ and $34^{\circ} \mathrm{S}$ Coastal Segment $(4, \mathrm{~W})$. In: BRINK, K. H.; ROBINSON, A. R. (Eds.). The sea, ideas and observations on progress in the study of the seas. New York: John Wiley, 1998. p. 209-251. [V.11 The global coastal ocean. Regional studies and syntheses].

CLARKE, K. R.; WARWICK, R. M. Change in marine communities: an approach to statistical analysis and interpretation. 2.ed. Oxford: Plymouth Marine Laboratory, 2001.

CORRÊA, C. E.; CHAVES, P. T.; GUIMARÃES, P. R. B. Biology of Chirocentrodon bleekerianus (Poey, 1867) (Clupeiformes: Pristigasteridae) in a continental shelf region of southern Brazil. Braz. Arch. Biol. Technol., v. 48, n. 3, p. 419-427, 2005.

GARRISON, L. P.; LINK, J. S. Dietary guild structure of the fish community in the Northeast United States continental shelf ecosystem. Mar. Ecol.: Prog. Ser., v. 202, p. 231-240, 2000a. 
GARRISON, L. P.; LINK, J. S. Fishing effects on spatial distribution and trophic guild structure of the fish community in the Georges Bank region. ICES J. Mar. Sci., v. 57, p. 723-730, 2000 b.

GERKING, S. D. Feeding ecology of fish. San Diego: Academic Press, 1994. 415 p.

GIANNINI, R.; PAIVA FILHO, A. M. Os Sciaenidae (Teleostei: Perciformes) da Baia de Santos (SP), Brasil. Bol. Inst. Oceanogr., v. 38, n. 1, p. 69-86, 1990.

HAJISAMAE, S.; IBRAHIM, S. Seasonal and spatial variations of fish trophic guilds in a shallow, semienclosed tropical estuarine bay. Environ. Biol. Fishes, v. 82, p. 251-264, 2008.

HAJISAMAE, S. Trophic ecology of bottom fishes assemblage along coastal areas of Thailand. Estuarine, Coastal Shelf Sci., v. 82, p. 503-514, 2009.

HYSLOP, E.J. Stomach content analysis: a review of methods and their application. J. Fish Biol., v. 17, n. 4, p. 411-429, 1980.

IBGE. Censo 2010. Disponível em: http://www.ibge.gov.br/home/estatistica/populacao/censo 2010/tabelas_pdf/Sao_paulo.pdf. Acesso em: 02 jun. 2012.

INSTITUTO DE PESCA. Estatística Pesqueira. Informe da produção pesqueira marinha e estuarina do Estado de São Paulo 2010. n. 5, 2011. Disponível em: ftp://ftp.sp.gov.br/ftppesca/1012InformePMAP.pdf. Acesso em: 02 jun. 2012.

INSTITUTO DE PESCA. Estatística Pesqueira. Informe da produção pesqueira marinha e estuarina do Estado de São Paulo 2011. n. 17, 2012. Disponível em: ftp://ftp.sp.gov.br/ftppesca/1212InformePMAP.pdf. Acesso em: 02 jun. 2012.

KAWAKAMI, E.; VAZZOLER, G. Método gráfico e estimativa do índice alimentar aplicado no estudo de alimentação de peixes. Bol. Inst. Oceanogr., v. 29, n. 2, p. 205-207, 1980.

LÓPEZ-PERALTA, R. H.; ARCILA, C. A. T. Diet composition of fish species from the southern continental shelf of Colombia. Naga, WorldFish Cent. Q., v. 25, n. 3/4, p. 23-29, 2002.

MARANCIK, K. E.; HARE, J. A. Large scale patterns in fish trophodynamics of estuarine and shelf habitats of the southeast United States. Bull. Mar. Sci., v. 80, n.1, p. 67-91, 2007.

MARION, C.; VASKE Jr., T.; GADIG, O. B. F.; MARTINS, I. A. Feeding habits of the shortnose guitarfish, Zapteryx brevirostris (Müller and Henle, 1841) (Elasmobranchii, Rhinobatidae) in southeastern Brazil. Braz. J. Biol., v. 71, n. 1, p. 83-89, 2011.

MARTINS, A. S.; HAIMOVICI, M.; PALACIOS, R. Diet and feeding of the cutlassfish Trichiurus lepturus in the Subtropical Convergence Ecosystem of southern Brazil. J. Mar. Biol., v. 85, p. 1223-1229, 2005.

MURANO, M. Mysidacea. In: BOLTOVSKOY, D. (Ed.) South Atlantic Zooplankton. Leiden: Backhuys Publ., 1999. p. 1099-1140.

MUTO, E. Y.; SOARES, L. S. H.; ROSSIWONGTSCHOWSKI, C. L. D. B. Demersal fish assemblage off São Sebastião, southeastern Brazil: structure and environmental conditioning factors (summer 1994). Rev. Bras. Oceanogr., v. 48, n. 1, p. 927, 2000 .
MUTO, E. Y.; SOARES, L. S. H.; GOITEIN, R. Food resource utilisation of the skates Rioraja agassizii (Müller and Henle, 1841) and Psammobatis extenta (McEachran, 1983) on the continental shelf off Ubatuba, southeastern Brazil. Rev. Bras. Biol., v. 61, n. 2, p. 217 238, 2001.

MUTO, E. Y.; MALFARA, D. T.; COELHO, L. I.; SOARES, L. S. H. Alimentação das sardinhas Pellona harroweri (Fowler, 1919) e Chirocentrodon bleekerianus (Poey, 1867), na região costeira de Santos, Estado de São Paulo. In: BRAGA, E.S. (Org.). Oceanografia e mudanças globais. São Paulo: Instituto Oceanográfico, 2008. p. 287-302.

MUTO, E. Y.; SOARES, L. S. H. Diet and dual stable isotopes of the Argentine hake Merluccius hubbsi Marine, 1933 on the continental shelf of southeastern Brazil. Mar. Biol., v. 158, n. 7, p. 1619-1630, 2011.

OMORI, M. The biology of pelagic shrimps in the ocean. In: RUSSELL, F. S.; YONGE, M. Advances in marine biology. London: Academic Press, 1975.v. 12, p. 233234.

PAIVA FILHO, A. M.; GIANNINI, R.; RIBEIRO NETO, F. B.; SCHMIEGELOW, J. M. M. Ictiofauna do complexo Baia-Estuário de Santos e São Vicente, SP, Brasil. São Paulo: Instituto Oceanográfico/USP, 1987. p. 1-10. (Relat. Int. Inst. Oceanogr.; n. 17).

PAULY, D.; CHISTENSEN, V.; DALSGAARD, J.; FROESE, R.; TORRES Jr., F. Fishing down marine food webs. Science, v. 279, n. 5352, p. 860-863, 1998.

PAULY, D.; WATSON, R. Background and interpretation of the Marine Trophic Index as a measure of biodiversity. Phil. Trans. R. Soc. B, v. 360, n. 1454, p. 415-423, 2005.

PÉREZ-ESPAÑA， H.; SAUCEDO-LOZANO, M. AND RAYMUNDO-HUIZAR, A. R. Trophic ecology of demersal fishes from the Pacific shelf off Central Mexico. Bull. Mar. Sci., v. 77, n.1, p. 19-31, 2005.

PETERSON, B. J. Stable isotopes as tracers of organic matter input and transfer in benthic food webs: a review. Acta Oecol., v. 20, n. 4, p. 479-487, 1999.

PETERSON, B. J.; FRY, B. Stable isotopes in ecosystem studies. Annu. Rev. Ecol. Syst., v. 18, p. 293-320, 1987.

PIRES, A.M.S. Structure and dynamics of benthic megafauna on the continental shelf offshore of Ubatuba, southeastern Brazil. Mar. Ecol.: Prog. Ser., v. 86, p. 6376, 1992.

PIRES-VANIN, A. M. S. Megafauna e macrofauna. In: PiresVanin, A. M. S. (Org.). Oceanografia de um ecossistema subtropical: plataforma de São Sebastião, SP. São Paulo: EDUSP, 2008a. p. 311-349.

PIRES-VANIN, A. M. S.; ROSSI-WONTSCHOWSKI, C. D. L. B.; AIDAR, E.; MESQUITA, H. S. L.; SOARES, L. S. H.; KATSURAGAWA, M.; MATSUURA, Y. Estrutura e função do ecossistema de plataforma continental do Atlântico Sul Brasileiro: síntese dos resultados. Publ. Esp. Inst. Oceanogr., n. 10, p. 217231, 1993.

PLATELL, M. E.; POTTER, I. C. Partitioning of food resources amongst 18 abundant benthic carnivorous fish species in marine waters on the lower west coast of Australia. J. Exp. Mar. Biol. Ecol., v. 26, p. 31-54, 2001. 
REUM, J. C. P.; ESSINGTON, T. E. Seasonal variation in guild structure of the Puget Sound demersal fish community. Estuaries Coasts, v. 31, p. 790-801, 2008.

ROCHA, G. R. A.; ROSSI-WONGTSCHOWSKI, C. L. D. B. Demersal fish community on the inner shelf of Ubatuba, southeastern Brazil. Rev. Bras. Oceanogr., v. 46, n. 2, p. 93-109, 1998.

RODRIGUES, E. S.; MEIRA, P. T. F. Dieta alimentar de peixes presentes na pesca dirigida ao camarão-setebarbas (Xiphopenaeus kroyeri) na baía de Santos e praia do Perequê, Estado de São Paulo, Brasil. Bol. Inst. Pesca, v. 15, n. 2, p. 135-146, 1988.

ROSSI-WONGTSCHOWSKI, C. L. D. B.; PAES, E. T. Padrões espaciais e temporais de peixes demersais do litoral norte do Estado de São Paulo - Ubatuba, Brasil. Publ. Esp. Inst. Oceanogr., v. 10, p. 169-188, 1993.

ROSSI-WONGTSCHOWSKI, C. L. D. B.; SOARES, L. S. H.; MUTO, E. Y. Ictiofauna. In: PIRES-VANIN, A. M. S. (Org.). Oceanografia de um ecossistema subtropical: plataforma de São Sebastião, SP. São Paulo: EDUSP, 2008. p. 381-404.

SÃO PAULO (Estado). Decreto n. 53.494, de 02 de outubro de 2008. Declara as espécies da fauna silvestre ameaçadas, as quase ameaçadas, as colapsadas, sobrexplotadas, ameaçadas de sobrexplotação e com dados insuficientes para avaliação no Estado de São Paulo e dá providências correlatas. Diário Oficial do Estado de São Paulo, São Paulo, Poder Executivo, n. 118 (187), 3 out. 2008a. Seção I, p.1-10.

SÃO PAULO (Estado). Decreto n. 53.526, de 8 de outubro de 2008. Cria a Área de Proteção Ambiental Marinha do Litoral Centro, e dá providências correlatas. Diário Oficial do Estado de São Paulo, São Paulo, Poder Executivo, n. 118 (191), 9 out. 2008b. Seção I, p. 2-10.

SEDBERRY, G. R.; FOELL, E. J.; MUSIK, J. A. Community structure analysis and food habits of fishes. In: LAIR, B. L. (Coord.). Middle Atlantic outer continental shelf environmental studies: chemical and biological. Woods Hole: Virginia Institute of Marine Life, Washington: Bureau of Land Management, 1979. v. 2C, cap. 9 (NTIS Technical Report). Disponível em: http://invertebrates.si.edu/boem/reports/CABP final exe c.pdf. Acesso em: dia Mês abrev. ano.

SOARES, L. S. H. Alimentação de Isopisthus parvipinnis (Teleostei: Sciaenidae) na baía de Santos, São Paulo. Bol. Inst. Oceanogr., v. 37, n. 2, p. 95-105, 1989.

SOARES, L. S. H.; ROSSI-WONGTSCHOWSKI, C. L. D. B.; ÁLVARES, L. M. C.; MUTO, E. Y.; GASALLA, M. A. Grupos tróficos de peixes demersais da plataforma continental interna de Ubatuba, Brasil. I. Chondrichthyes. Bol. Inst. Oceanogr., v. 40, n. 1/2, p. 79-85, 1992.

SOARES, L. S. H.; GASALLA, M. A.; RIOS, M. A. T.; ARRASA, M. V.; ROSSI-WONGTSCHOWSKI, C. L. D. B. Grupos tróficos de onze espécies dominantes de peixes demersais da plataforma continental interna de Ubatuba, Brasil. Publ. Esp. Inst. Oceanogr., v. 10, p. 189-198, 1993.

SOARES, L. S. H.; VAZZOLER, A. E. A. M. Diel changes in food and feeding activity of sciaenid fishes from the South-western Atlantic, Brazil. Rev. Bras. Biol., v. 61, n. 2, p. 197-216, 2001

SOARES, L. S. H.; MUTO, E. Y.; GASPARRO, M. R.; ROSSI-WONGTSCHOWSKI, C. L. D. B. Organização trófica dos peixes. In: PIRES-VANIN, A. M. S. (Org.). Oceanografia de um ecossistema subtropical: plataforma de São Sebastião, SP. São Paulo: EDUSP, 2008. p. 404-428.

SOUZA, U. P.; COSTA, R. C.; MARTINS, I. A.; FRANSOZO, A. Associações entre as biomassas de peixes Sciaenidae (Teleostei: Perciformes) e de camarões Penaeoidea (Decapoda: Dendrobranchiata) no litoral norte do Estado de São Paulo. Biota Neotrop., v. 8, n. 1, p. 83-92, 2008.

VALENTINNI, H.; CASTRO, P. M. C.; SERVO, G. J. M.; CASTRO, L. A. B. Evolução da pesca das principais espécies demersais da costa sudeste do Brasil, pela frota de arrasteiros de parelha baseada em São Paulo, de 1968 a 1987. Atlântica, v. 13, n. 1, p. 87-95, 1991.

VERA, G. R.; SOARES, L. S. H. Variabilidade alimentar de Raneya brasiliensis na plataforma continental de Ubatuba e Cabo Frio, Brasil. In: BRAGA, E.S. (Org.). Oceanografia e mudanças globais. São Paulo: Instituto Oceanográfico, 2008. 303-315 p.

\section{Sources of Unpublished Material}

HEITOR, S. R.; TOMMASI, R. Estrutura da macrofauna bentônica sob influência de lançamento de esgoto através de emissário submarino na baía de Santos, São Paulo, Brasil. In: CONGRESSO LATINO AMERICANO SOBRE CIÊNCIAS DEL MAR, 9., San Andrés Isla, 2001. Resumen Ampliado. San Andrés Isla, 2001. p. 16-20.

MUTO, E. Y. Variações isotópicas de ${ }^{13} \mathrm{C}$ e ${ }^{15} \mathrm{~N}$ de peixes demerso-pelágicos do ecossistema de plataforma ao largo de Cabo Frio (RJ) e Ubatuba (SP). 142 p. Tese (Doutorado) - Instituto Oceanográfico, Universidade de São Paulo, São Paulo, 2004.

PIRES-VANIN, A. M. S.; FERREIRA, J. A.; BROMBERG, S.; SOUZA, A. M. T.; RODRIGUES, C. W.; HATAMURA, M. P. Bentos. In: PIRES-VANIN, A. M. S. (Coord.). "A influência do complexo estuarino da Baixada Santista sobre o ecossistema da plataforma adjacente" - ECOSAN: Período: Julho/2005 a Junho/2007. São Paulo: Instituto Oceanográfico, Universidade de São Paulo, 2006. (Relatório FAPESP; n. II - Processo n. 03/09932-1). [Projeto].

PIRES-VANIN, A. M. S.; FERREIRA, J. A.; BROMBERG, S.; SOUZA, A. M. T.; RODRIGUES, C. W.; SHIMABUKURU, M. Bentos. In: PIRES-VANIN, A. M. S. (Coord.). Projeto: "A influência do complexo estuarino da Baixada Santista sobre o ecossistema da plataforma adjacente" - ECOSAN: Período: Julho/2006 a Junho/2007. São Paulo: Instituto Oceanográfico, Universidade de São Paulo, 2007. (Relatório FAPESP; n. III - Processo n. 03/09932-1). [Projeto].

PIRES-VANIN, A. M. S.; BROMBERG, S.; FERREIRA, J. A.; RODRIGUES, C. W.; SHIMABUKURU, M. Bentos. In: PIRES-VANIN, A. M. S. (Coord.). Projeto: "A influência do complexo estuarino da Baixada Santista sobre o ecossistema da plataforma adjacente" ECOSAN: Período: Julho/2007 a Julho/2008. São Paulo: Instituto Oceanográfico, Universidade de São Paulo, 2008b. (Relatório FAPESP; n. IV - Processo n. 03/09932-1). [Projeto]. 